\title{
Mangroves of Sri Lanka: Distribution, status and conservation requirements
}

\author{
A. K. H. Priyashantha ${ }^{1} *$ and T. Taufikurahman ${ }^{2}$ \\ ${ }^{1}$ Department of Multidisciplinary Studies, Faculty of Technology, Eastern University, Sri Lanka \\ ${ }^{2}$ School of Life Sciences and Technology, Institut Teknologi Bandung, Indonesia \\ *Corresponding Author: priyashanthahasith@gmail.com \\ [Accepted: 12 December 2020]

\begin{abstract}
Mangroves are a diverse group of highly salt-tolerant woody plants, which grow in the inter-tidal zones in tropical and subtropical latitudes. Despite its unique services to the people, coastal and marine systems, mangroves have become one of the most rapidly disappearing ecosystems in the world. This paper reviews the available information on distribution, current status and challenges of mangroves in Sri Lanka. Today, around $160 \mathrm{~km}^{2}$ of mangrove vegetation is available in Sri Lanka and distributed mainly in Jaffna, Batticaloa, Kalpitiya, Rekawa and Trincomalee and is composed of 21 species of true mangroves and 24 species of mangrove associates. Mangroves in the island have been adversely affected due to the numerous anthropogenic activities, including land reclamation, tourism, coastal aquaculture and agriculture and other industrial activities etc. Proper conservations of mangroves are urgently required to the island to avoid further decline of mangrove ecosystem. It is imperative to evaluate policies, legal instruments and development strategies to effectively protect this valuable ecosystem.
\end{abstract}

Keywords: Challenges - Conservation - Current status - Protection of mangroves.

[Cite as: Priyashantha AKH \& Taufikurahman T (2020) Mangroves of Sri Lanka: Distribution, status and conservation requirements. Tropical Plant Research 7(3): 654-668]

\section{INTRODUCTION}

Mangroves are one of the most productive ecosystems in the world (Zvonareva et al. 2015). They may be either shrubs or small trees and primarily marginalize the intertidal zone along with sheltered coastal, estuarine and riverine areas in tropical and subtropical latitudes, and they also occur in coastal lagoons and the supralittoral zone (Ashton 2008). Being living at the interface between land and sea, mangroves are highly adapted to cope with the harsh conditions, such as high salinity, extreme tides, strong winds, high temperatures, muddy and anaerobic soils (Kathiresan \& Bingham 2001, Reef \& Lovelock 2015, Wen et al. 2016). Mangroves are well recognized owing to its unique ecological functions, services and socio-economic values (Devi \& Pathak 2016, Das et al. 2019). Mangrove forests provide protection and feeding and rearing habitats for many fish species, crustaceans, shellfish and hence support local and commercial fisheries (Alongi 2002, Boone \& Bhomia 2017, Yaney-Keller et al. 2019).

Mangroves also provide a breeding ground for birds, reptiles and mammals (Alongi 2002, Walters et al. 2008). The ecosystem also plays an important role in purifying water and protection against salt intrusion, protection of nearby beaches and coral reefs, supplying nutrient resources, carbon sequestration and land stabilization (Gunawardena \& Rowan 2005, Walters et al. 2008, Guannel et al. 2016, Weiss et al. 2016, Gao et al. 2019, Van der Stocken et al. 2019). Moreover, mangrove vegetation acts as a bio-shield, against high energy waves and storm surges during extreme weather conditions and hence protect the coastlines and human settlements (Das \& Vincent 2009, Boone \& Bhomia 2017, Walcker et al. 2019). Mangroves are also traditionally used by locals for food, timber, fuel and medicine (Alongi 2002). As reported by Hrudayanath et al. (2016), about 84 mangrove species belonging to 24 genera and 16 families, have been identified in the world. 11 mangroves have been categorized as threatened species by IUCN (International Union for Conservation of Nature) (Saddhe et al. 2016). 
Sri Lanka is a small tropical island (about 65,610 $\mathrm{km}^{2}$ ), which lies in the Indian Ocean, a few kilometers away from the southeastern coast of India (Arulpragasam 2000, Geekiyanage et al. 2015). Being an island nation, Sri Lanka is enriched with beaches, sand bars and spits, estuaries, lagoons and bays, sand dunes and mangrove ecosystems (Nayanananda 2007). Importance as well as attention of the mangrove ecosystem was gained more after Tsunami, which is hit Sri Lanka on $26^{\text {th }}$ December 2004 and coastal strip (1,700 km long) of Sri Lanka was heavily destructed due to this tragedy, including the mangrove ecosystem (Nayanananda 2007, Samarakoon \& Samarawickrama 2012). According to Ranawana (2017), about $160.12 \mathrm{~km}^{2}$ of mangrove forests can be found in the island. Most of the mangrove forest areas in the island have been subjected to human interference and therefore, undisturbed mangrove forests are rarely found (Gunawardena et al. 2016).

While moving to the global, it was estimated that about $152,000 \mathrm{~km}^{2}$ of the global area (Nabeelah Bibi et al. 2019 ) is occupied by the mangroves and represented about $0.12 \%$ of the Earth's terrestrial surface (Moity et al. 2019). Mangroves can be found in 123 countries in the world (Mukherjee et al. 2014). Among them, Indonesia is the country, which is having the largest mangrove coverage in the world, representing $25.79 \%$ of the global total (Nabeelah Bibi et al. 2019). Apart from that, Brazil, Malaysia, Venezuela, Nigeria, Papua New Guinea, Colombia, Mexico, Thailand and Gabon are the top ranked countries based on the mangrove distribution area (Fig. 1).

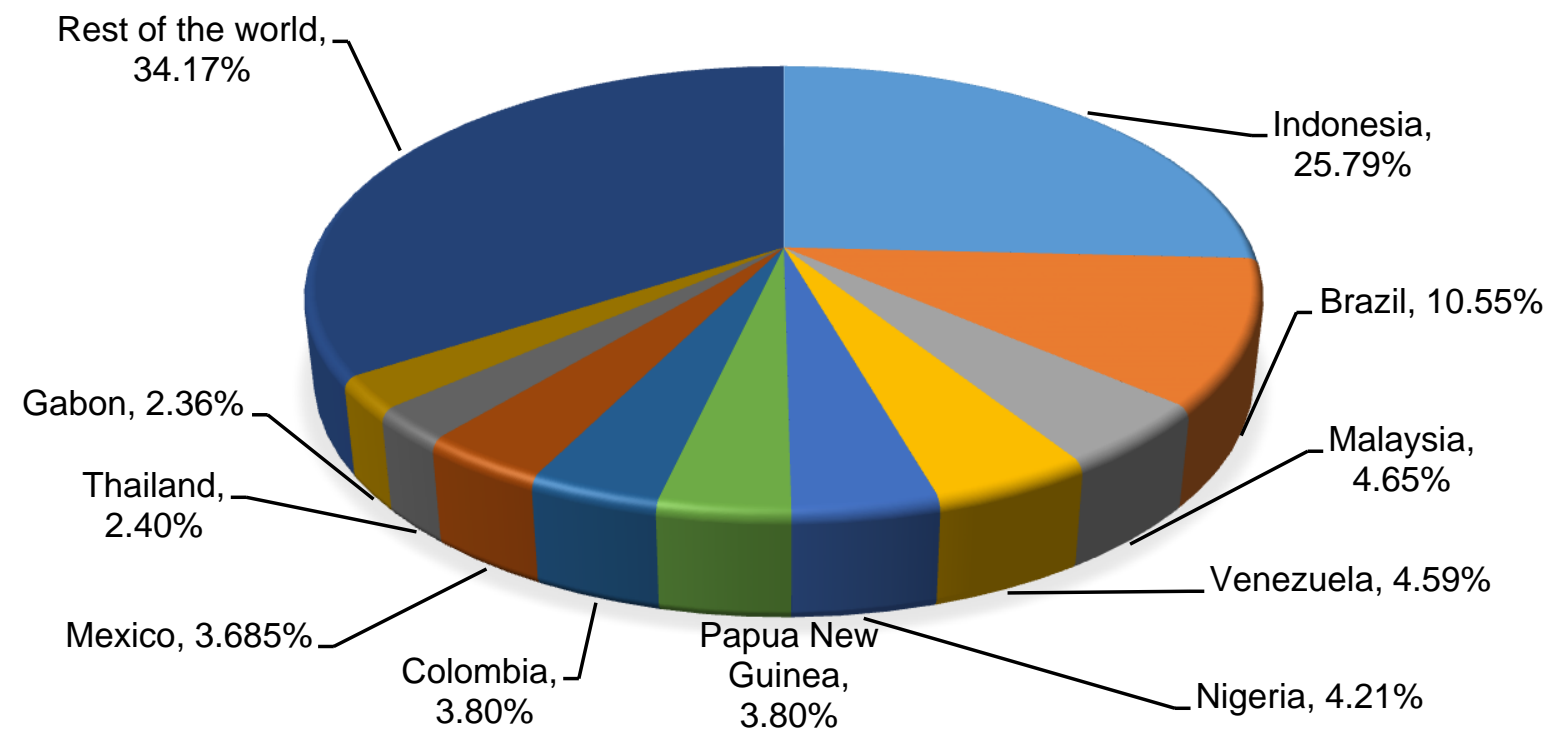

Figure 1. Global percentage of mangrove distribution: Indonesia, Brazil, Malaysia, Venezuela, Nigeria, Papua New Guinea, Colombia, Mexico, Thailand and Gabon are the top (10) ranked countries with 42278, 17287, 7616, 7516, 6908, 6236, 6236, 6036,3936 and $3864 \mathrm{~km}^{2}$ area coverage respectively. Mangrove percentage of those countries with respect to the global are 25.79, 10.55, 4.65 and 4.59 etc. respectively. [Source: Nabeelah Bibi et al. (2019)]

Because of its significance, mangroves are protected by the laws, rules and regulations in the world (Andrade et al. 2018). However, over the past century, a significant decline of mangrove coverage was observed throughout the world (Blankespoor et al. 2017, Menéndez et al. 2019). The most extensive losses have been recorded in Asia, followed by Africa, and North and Central America (Pham et al. 2019). It was estimated that during the past 50 years, approximately $30-50 \%$ of natural mangroves were destroyed in the world (Gao et al. 2019). During the 1980s, Indonesia, Mexico, Pakistan, Papua New Guinea and Panama recorded the largest losses of mangroves, which shared a loss of 0.01 million square kilometers (FAO 2007).

It is estimated that, about 0.036 million $\mathrm{km}^{2}$ of mangrove vegetation have been lost in the world including Vietnam, Thailand, Philippines, Myanmar, Brazil, China, Malaysia, Bangladesh, and India (Paul \& Vogl 2011, Asbridge et al. 2016, Ahmed et al. 2018). Furthermore, during 1980 to 2000, about 1.04\% of average annual losses of mangrove forests were recorded. However, comparatively fewer annual losses $(0.66 \%)$ were recorded from 2000 to 2005. The average loss rates between 2000 and 2012 may have stabilized or further declined (Blankespoor et al. 2017). It also predicted that the decline of mangrove forests will be at the current rate in the next couple of years, unless it is managed based on a sustainable strategy (Alongi 2002). Habitat destruction has been the primary cause of mangrove decline in the world (Kathiresan \& Bingham 2001), where more than 50\% of mangroves were lost between 1950 and 2000 in China due to habitat destruction (Wu et al. 2018). Anthropogenic activities are the prime cause for mangrove destruction rather than natural events and processes (Satyanarayana et al. 2012, Asbridge et al. 2018). 
The most dominant threats from anthropogenic activities to the mangrove destructions are aquaculture practices, salt farming, tourism, urbanization and overexploitation of mangrove timber (Kathiresan \& Bingham 2001, Adame et al. 2013, Blankespoor et al. 2017, Nehemia \& Kochzius 2017). Mangrove dynamics are also affected by the intense storms, tsunami conditions, changes in freshwater run-off, salinity regime and tidal flow patterns, changing sea levels and excessive siltation (Katupotha 2001, Asbridge et al. 2018, Gandhi \& Jones 2019). It is also identified that mangrove areas, which are located close to densely populated urban or rural settlements are often vulnerable to degradation (Satyanarayana et al. 2013). Mangrove losses in countries like Myanmar and Indonesia are at a fast rate. Annual mangrove loss rate in Indonesia is double compared with the global average (Hamilton \& Casey 2016).

True mangroves and mangrove associates

Mangroves are classified into two as "true mangroves" or "obligate mangroves" and "mangrove associates" or "semi-mangroves" (Wang et al. 2011a, b). True mangroves habitat only in mangrove forests and are not found in terrestrial communities. They are also morphologically specialized to the mangrove environment and bear specialized morphological adaptations such as aerial roots, buttresses, salt-excretion through leaves, buoyant and viviparous propagules (Quadros et al. 2017). Mangrove associates may occur as transitional vegetation between true mangroves and the terrestrial vegetation, without featuring all the highly specific adaptations as developed in true mangroves (FAO 2007).

Species composition and distribution of mangroves in Sri Lanka

Since the tidal amplitude is very low $(<1 \mathrm{~m})$ in Sri Lanka, the distribution of mangrove forests are confined to a narrow strip (Bambaradeniya et al. 2002). The mangrove coverage of the island is only about $0.1-0.2 \%$ of the total land area (Weragodatenna \& Gunaratne 2015). Mangrove vegetation can be found in the island along the coastal belt, covering 14 (out of 25) administrative districts; Jaffna, Kilinochchi, Mullaitivu, Trincomalee, Batticaloa, Ampara, Hambantota, Matara, Galle, Kalutara, Colombo, Gampaha, Puttalam and Mannar (Fig. 2) (Kaleel \& Nijamir 2017). Mangroves are associated with many of lagoons and estuaries in the island, and hence show patchy distribution (Karunathilake 2003).

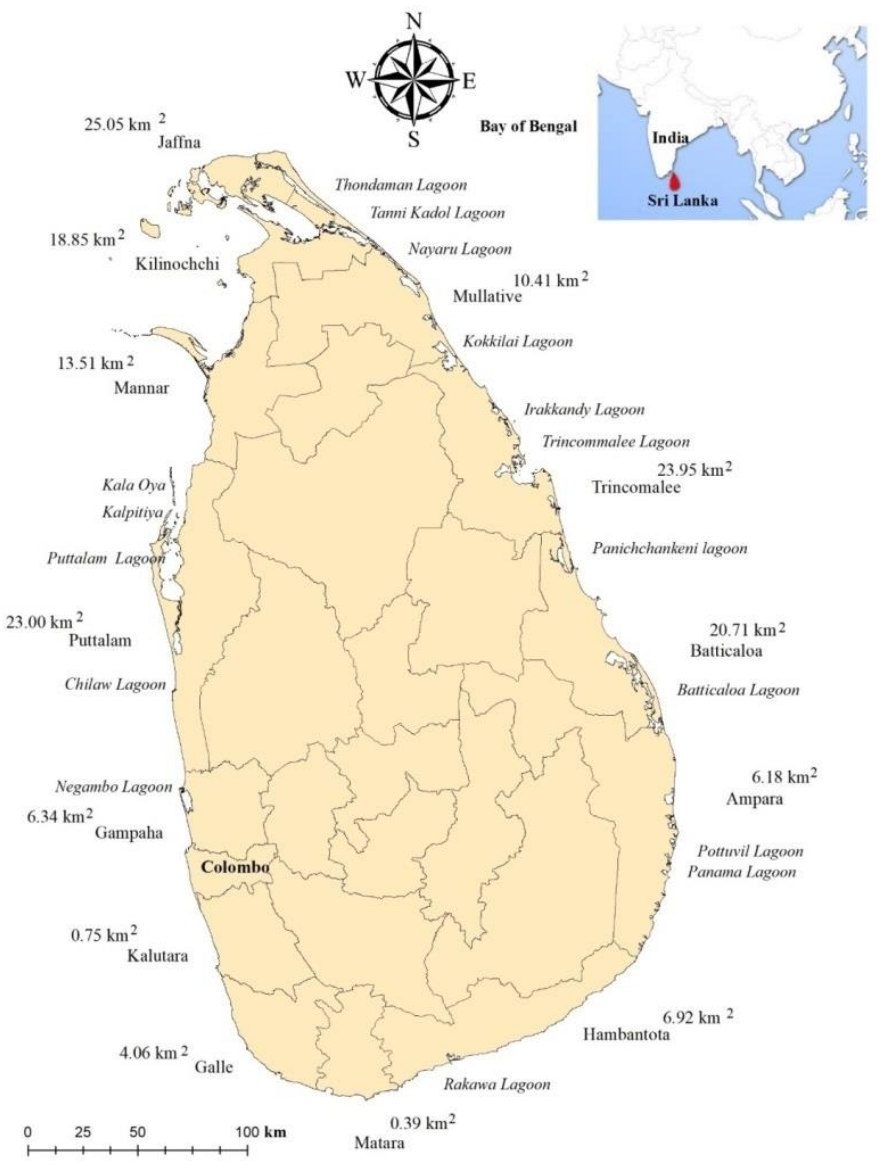

Figure 2. Distribution of mangroves in Sri Lank and its coverage, respect with coastal districts. [Source: Ranawana 2017]

Extensive mangrove patches can be found in the northwestern and northeastern coastlines. The largest patch is associated with Puttlam-Kalpitiya lagoon and the second-largest is located in Jaffna peninsula. Mangrove www.tropicalplantresearch.com 
forests in Trincomalee and Batticaloa are holding third place in this list (Karunathilake 2003). Less populations in eastern and the northwest part of Sri Lanka could be one of the reasons to have a higher amount of mangroves (Mathanraj \& Kaleel 2015). According to Jayatissa (2012) Sri Lanka is enriched with 21 true mangrove species (Table 1) and 24 mangroves associates.

Table 1. Sri Lankan list of true mangrove species

\begin{tabular}{ll}
\hline Family & Species \\
\hline Avicenniaceae & Avicennia marina (Forsk.) Vierh., Avicennia officinalis L. \\
Combretaceae & Lumnitzera littorea (Jack) Voigt, Lumnitzera racemose Willd. \\
Euphorbiaceae & Excoecaria agallocha L., Shirakiopsis indica (Willd.) Esser \\
Lythraceae & Pemphis acidula J.R. \& G. Forst. \\
Meliaceae & Xylocarpus granatum Koenig \\
Myrsinaceae & Aegiceras corniculatum (L.) Blanco \\
Palmae & Nypa fruticans Wurmb. \\
Rhizophoraceae & Bruguiera cylindrica (L.) Blume, Bruguiera gymnorhiza (L.) Lamk., Bruguiera \\
& Sexangula (Lour.) Poir., Ceriops decandra (Griff.) Ding Hou, Ceriops tagal \\
Rubiaceae & (Perr.) C.B. Rob., Rhizophora apiculata Bl., Rhizophora mucronata Poir. \\
Sonneratiaceae & Scyphiphora hydrophyllacea Gaertn.f. \\
Sterculaceae & Sonneratia alba J. Smith, Sonneratia caseolaris (L.) Engler \\
\hline Source: Jayanditiera littoralis Dryand.
\end{tabular}

Source: Jayathissa (2012).

Among the true mangrove species, three are categorized as endangered species, viz., Ceriops decandra (Griff.) W.Theob., Lumnitzera littorea (Jack) Voigt and Sonneratia apetala Buch.-Ham. (Jayatissa 2012, Sarathchandra et al. 2018). Most common true mangrove species include; Rhizophora mucronata Lam., Avicennia marina (Forsk.) Vierh., Excoecaria agallocha L., Lumnitzera racemosa Willd., Sonneratia caseolaris (L.) Engler, Bruguiera gymnorhiza (L.) Lamk. and Aegiceras corniculatum (L.) Blanco. In addition to the three endangered species indicated above, Scyphiphora hydrophyllacea Gaertn.f. and Cynometra iripa Kostel. are considered as rare species (Gunawardena et al. 2016). Among the mangrove associates, Acanthus ilicifolius L., Hibiscus tiliaceus L., Premna integrifolia L., Thespesia populnea (L.) Solander ex Correa, Acrostichum aureum L., Clerodendrum inerme (L.) Gaertn. (Fig. 3) are the most common species (Jayatissa 2012, Kaleel \& Nijamir 2017). Also, in Sri Lanka, endemic species are not found among either true mangrove species or mangrove associates (Jayatissa 2012).

Five types of mangrove vegetation (riverine, fringing, scrub, over-wash and basin) based on the topography, flooding characteristics and floristic composition can be found in the island (Bambaradeniya et al. 2002). However, among them riverine and fringing mangroves are the most common types in the island (Jayatissa 2012). For example, Nypa fruticans Wurmb., Sonneratia caseolaris, Rhizophora apiculata Bl. and Bruguiera sexangula (Lour.) Poir. have been reported from riverine mangroves, while Rhizophora mucronata, Ceriops tagel (Perr.) C.B. Robinson, Sonneratia alba J. Smith and Avicennia marina are dominating as fringing mangroves (Gunatilleke et al. 2008). Species distribution in the island shows considerable differences, even though they are in the same climatic region or the geographic. This may be due to the hydrology, soil salinity variations and other edaphic factors such as soil nutrition, texture and bulk density in the area (Prasanna et al. 2019). As an example, Avicennia marina is dominant in the island along with high salinity areas such as southern and western parts of the island (Rajkumar et al. 2019). In Sri Lanka mangroves are mainly occur in five provinces; Western, North Western, Northern, Eastern and Southern (Table 2).

Mangroves in Western and North Western Provinces

A study conducted by Prakash and co-workers. (2017) identified that 16 mangrove species, belonging to 9 families are associated with Muthurajawela and Negombo Lagoons, west coast of Sri Lanka (Table 3). However, while moving to north-western coast, Kala oya estuary supports the largest and least disturbed mangrove forest in the island, with an area coverage of over $18.37 \mathrm{~km}^{2}$, which belongs to $65 \%$ of the mangroves in Dutch bay. In adition to Kala oya, undisturbed mangrove patches can also be found in Kuringipitti, Pubudugama, Gangewadiya, Thirikkapallama, Ettalai and in most of islands such as Ippantivu, Sinnaarichchalai, Periyaarichchalai and Irrimathivu (IUCN, 2012). Kala oya estuary is also enriched with 8 true mangrove species [Aegiceras corniculatum, Avicennia marina, Bruguiera cylindrica (L.) Blume, Bruguiera gymnorrhiza (L.) Lam., Ceriops tagal (Perr.) C.B. Rob., Excoecaria agallocha, Lumnitzera racemose Willd. and Rhizophora mucronata], while Rhizophora mucronata is the most abundant species followed by Excoecaria agallocha and Lumnitzera racemose, while Aegiceras corniculatum shows the least abundancy (Perera et al. 2013). 

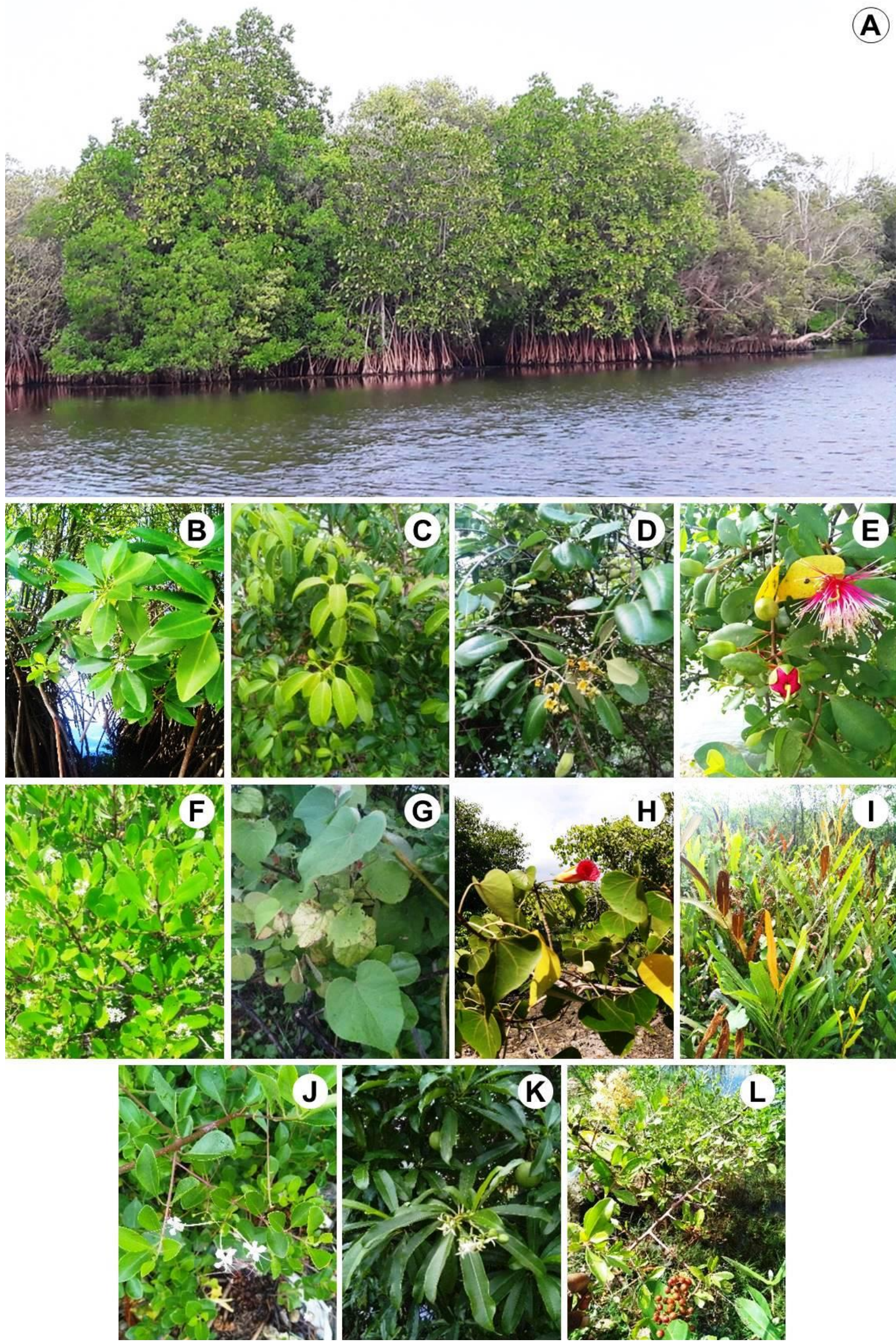

Figure 3. A, Wealthy mangrove forest and some of mangrove species of Sri Lanka; B, Rhizophora mucronata Lam.; C, Excoecaria agallocha L.; D, Avicennia officinalis L.; E, Sonneratia caseolaris (L.) Engler; F, Lumnitzera racemosa Willd.; G, Hibiscus tiliaceus L.; H, Thespesia populnea (L.) Solander ex Correa; I, Acrostichum aureum L.; J, Clerodendrum inerme (L.) Gaertn.; K, Cerbera manghas L.; L, Premna integrifolia L. 
Table 2. List of true mangrove species distribution in Sri Lanka.

\begin{tabular}{|c|c|c|c|c|c|c|}
\hline \multirow[t]{2}{*}{ Mangrove species } & \multicolumn{5}{|c|}{ Distribution } & \multirow[t]{2}{*}{ References } \\
\hline & WP & NWP & NP & EP & SP & \\
\hline Aegiceras corniculatum (L.) Blanco & $\sqrt{ }$ & $\sqrt{ }$ & $\sqrt{ }$ & $\sqrt{ }$ & $\sqrt{ }$ & $1,2,4,8,11,13$ \\
\hline Avicennia marina (Forsk.) Vierh. & $\sqrt{ }$ & $\sqrt{ }$ & $\sqrt{ }$ & $\sqrt{ }$ & $\sqrt{ }$ & $1,2,4,6,8,9,10,11,12$ \\
\hline Avicennia officinalis L. & $\sqrt{ }$ & $\sqrt{ }$ & $\sqrt{ }$ & $\sqrt{ }$ & $\sqrt{ }$ & $1,2,8,11,13$ \\
\hline Bruguiera cylindrica (L.) Blume & $\sqrt{ }$ & $\sqrt{ }$ & $\sqrt{ }$ & $\sqrt{ }$ & $\mathrm{x}$ & $1,3,4,7,8$ \\
\hline Bruguiera gymnorhiza (L.) Lamk. & $\sqrt{ }$ & $\sqrt{ }$ & $\sqrt{ }$ & $\sqrt{ }$ & $\sqrt{ }$ & $1,2,4,8$ \\
\hline Bruguiera sexangula (Lour.) Poir. & $\sqrt{ }$ & $\sqrt{ }$ & $\mathrm{x}$ & $\sqrt{ }$ & $\sqrt{ }$ & $8,13,2$ \\
\hline Ceriops decandra (Griff.) Ding Hou & $\sqrt{ }$ & $\sqrt{ }$ & $\mathrm{x}$ & $\sqrt{ }$ & $\mathrm{x}$ & 1 \\
\hline Ceriops tagal (Perr.) C.B. Rob. & $\sqrt{ }$ & $\sqrt{ }$ & $\mathrm{x}$ & $\mathrm{x}$ & $\sqrt{ }$ & $2,4,8$ \\
\hline Excoecaria agallocha $\mathrm{L}$. & $\sqrt{ }$ & $\sqrt{ }$ & $\sqrt{ }$ & $\sqrt{ }$ & $\sqrt{ }$ & $1,2,4,5,6,8,10,11,12,13$ \\
\hline Shirakiopsis indica (Willd.) Esser & $\mathrm{x}$ & $\sqrt{ }$ & $\mathrm{x}$ & $\mathrm{x}$ & $\sqrt{ }$ & 2 \\
\hline Heritiera littoralis Dryand. & $\sqrt{ }$ & $\sqrt{ }$ & $\sqrt{ }$ & $\sqrt{ }$ & $\sqrt{ }$ & $1,2,6,8,11$ \\
\hline Lumnitzera littorea (Jack) Voigt & $\sqrt{ }$ & $\mathrm{x}$ & $\mathrm{x}$ & $\mathrm{x}$ & $\sqrt{ }$ & 2 \\
\hline Lumnitzera racemose Willd. & $\sqrt{ }$ & $\sqrt{ }$ & $\sqrt{ }$ & $\sqrt{ }$ & $\sqrt{ }$ & $1,2,4,6,8,10,11,12,13$ \\
\hline Nypa fruticans Wurmb. & $\sqrt{ }$ & $\sqrt{ }$ & $\mathrm{x}$ & $\mathrm{x}$ & $\sqrt{ }$ & 2,8 \\
\hline Pemphis acidula J.R. \& G. Forst. & $\sqrt{ }$ & $\sqrt{ }$ & $\mathrm{x}$ & $\sqrt{ }$ & $\sqrt{ }$ & 2,13 \\
\hline Rhizophora apiculata $\mathrm{Bl}$. & $\sqrt{ }$ & $\sqrt{ }$ & $\mathrm{x}$ & $\sqrt{ }$ & $\sqrt{ }$ & $1,2,5,6,8,9$ \\
\hline Rhizophora mucronata Lam. & $\sqrt{ }$ & $\sqrt{ }$ & $\sqrt{ }$ & $\sqrt{ }$ & $\sqrt{ }$ & $1,2,4,5,8,9,11,14$ \\
\hline Scyphiphora hydrophyllacea Gaertn.f. & $\mathrm{x}$ & $\sqrt{ }$ & $\sqrt{ }$ & $\mathrm{x}$ & $\mathrm{x}$ & 1,2 \\
\hline Sonneratia alba J. Smith & $\sqrt{ }$ & $\sqrt{ }$ & $\mathrm{x}$ & $\mathrm{x}$ & $\mathrm{x}$ & $2,8,9$ \\
\hline Sonneratia caseolaris (L.) Engler & $\sqrt{ }$ & $\sqrt{ }$ & $\sqrt{ }$ & $\sqrt{ }$ & $\sqrt{ }$ & $1,2,8$ \\
\hline Xylocarpus granatum Koenig & $\sqrt{ }$ & $\sqrt{ }$ & $\mathrm{x}$ & $X$ & $\sqrt{ }$ & 2,8 \\
\hline Total number of Species & 19 & 21 & 10 & 14 & 17 & \\
\hline
\end{tabular}

Note: $\sqrt{ }$ - Presence of the species, $x$ - Absence (or not recorded) of the species; WP- Western Province, NWP- North Western Province, NP- Northern Province, EP- Eastern Province, SP- Southern Province.

Sources: 1. De Silva \& De Silva (1998); 2. Jayatissa et al. (2002); 3. IUCN (2012); 4. Perera et al. (2013); 5. Perera \& Amarasinghe (2014); 6. Krishnanantham et al. (2015); 7. Packiyanathan \& Wijesundara (2016); 8. Prakash et al. (2017); 9. Gunathilaka \& Chandrasekara (2017); 10. Alawathugoda et al. (2018); 11. Ellepola et al. (2018); 12. Priyashantha (2018); 13. Prasanna et al. (2019); 14. Rajkumar et al. (2019).

Table 3. Distribution of different mangrove species in the west coast of Sri Lanka.

\begin{tabular}{|c|c|c|c|c|c|}
\hline Mangrove species & $\begin{array}{r}\text { Negambo } \\
\text { Lagoon }\end{array}$ & $\begin{array}{r}\text { Dandugan } \\
\text { Oya }\end{array}$ & $\begin{array}{r}\text { Hamilton } \\
\text { Canal }\end{array}$ & $\begin{array}{l}\text { Dutch } \\
\text { Canal }\end{array}$ & $\begin{array}{l}\text { Ja-ela } \\
\text { Canal }\end{array}$ \\
\hline Aegiceras corniculatum (L.) Blanco & $\sqrt{ }$ & $\mathrm{X}$ & $\mathrm{x}$ & $\mathrm{x}$ & $\mathrm{X}$ \\
\hline Avicennia marina (Forsk.) Vierh. & $\sqrt{ }$ & $\mathrm{x}$ & $\mathrm{x}$ & $\mathrm{x}$ & $\mathrm{x}$ \\
\hline Avicennia officinalis L. & $\sqrt{ }$ & $\mathrm{x}$ & $\mathrm{x}$ & $\mathrm{x}$ & $\mathrm{x}$ \\
\hline Bruguiera cylindrica (L.) Blume & $\sqrt{ }$ & $\mathrm{x}$ & $\mathrm{x}$ & $\mathrm{x}$ & $\mathrm{x}$ \\
\hline Bruguiera gymnorhiza (L.) Lamk. & $\sqrt{ }$ & $\sqrt{ }$ & $\sqrt{ }$ & $\sqrt{ }$ & $\sqrt{ }$ \\
\hline Bruguiera sexangula (Lour.) Poir. & $\sqrt{ }$ & $\sqrt{ }$ & $\sqrt{ }$ & $\sqrt{ }$ & $\sqrt{ }$ \\
\hline Ceriops tagal (Perr.) C.B. Rob. & $\sqrt{ }$ & $\mathrm{x}$ & $\mathrm{x}$ & $\mathrm{x}$ & $\mathrm{x}$ \\
\hline Rhizophora apiculata $\mathrm{Bl}$. & $\sqrt{ }$ & $\sqrt{ }$ & $\mathrm{x}$ & $\mathrm{x}$ & $\mathrm{x}$ \\
\hline Rhizophora mucronata Lam. & $\sqrt{ }$ & $\mathrm{x}$ & $\mathrm{x}$ & $\mathrm{x}$ & $\mathrm{x}$ \\
\hline Excoecaria agallocha $\mathrm{L}$. & $\sqrt{ }$ & $\sqrt{ }$ & $\sqrt{ }$ & $\sqrt{ }$ & $\sqrt{ }$ \\
\hline Heritiera littoralis Dryand. & $\sqrt{ }$ & $\sqrt{ }$ & $\mathrm{x}$ & $\mathrm{x}$ & $\mathrm{x}$ \\
\hline Lumnitzera racemosa Willd. & $\sqrt{ }$ & $\mathrm{x}$ & $\mathrm{x}$ & $\mathrm{x}$ & $\mathrm{x}$ \\
\hline Nypa fruticans Wurmb. & $\mathrm{X}$ & $\sqrt{ }$ & $\sqrt{ }$ & $\sqrt{ }$ & $\sqrt{ }$ \\
\hline Sonneratia alba J. Smith & $\sqrt{ }$ & $\mathrm{x}$ & $\mathrm{x}$ & $\mathrm{X}$ & $\mathrm{X}$ \\
\hline Sonneratia caseolaris (L.) Engler & $\sqrt{ }$ & $\sqrt{ }$ & $\sqrt{ }$ & $\sqrt{ }$ & $\sqrt{ }$ \\
\hline Xylocarpus granatum Koenig & $\sqrt{ }$ & $\mathrm{x}$ & $\mathrm{x}$ & $\mathrm{x}$ & $\mathrm{x}$ \\
\hline Total number of Species & 15 & 7 & 5 & 5 & 5 \\
\hline
\end{tabular}

Note: $\sqrt{ }$ - Presence of the species, $\mathrm{x}$ - Absence (or not recorded) of the species. [Source: Prakash et al. (2017)]

About $12 \mathrm{~km}^{2}$ of mangrove area was covered around the Puttalam lagoon early and $39 \%$ of this mangrove forest has disappeared by 1994 due to the anthropogenic activities and the destruction is still to be stopped (Amarasinghe 1997). In a study by Gunathilaka \& Chandrasekara. (2017), 15 total mangrove species (8 True mangrove species and 7 mangrove associates) belonging to 13 genera and 9 families were associated with Puttalam lagoon.

Rhizophora mucronata and Avicennia marina were the major constituent mangrove species of Puttalam lagoon area and also in the Dutch bay. Avicennia marina can be identified as mono-specific and stands in many places associated with the lagoon. While Rhizophora mucronata is distributed widely in water-front areas of 
Kala Oya and Mi Oya, rare species Scyphiphora hydrophyllacea also can found in associated with Puttalam lagoon in a few locations. Xylocarpus rumphii (Kostel.) Mabb. was also restricted to a few small islands in the Puttalam lagoon area (as well as in Wilpattu National Park and Unawatuna Beach) (IUCN 2012). Restrictied distribution of Bruguiera cylindrica can was also found along the lagoon areas of Chilaw and small islands of Kalpitiya area (IUCN 2012).

Mangroves in Northern Province

Jaffna peninsula bears some large extents of undisturbed mangrove forests (Packiyanathan \& Wijesundara 2016). Excoecaria agallocha, Lumnitzera racemosa and Avicennia marina are the most frequently found species in Northern Province, including Jaffna, Mullaithivu, Kilinochchi and Mannar districts (Alawathugoda et al. 2018), While, Rhizophora mucronata is also one of the most common species in the Jaffna district (Rajkumar et al. 2019). Also, Bruguiera cylindrica shows a much restricted distribution (Packiyanathan \& Wijesundara 2016), while Avicennia marina shows dominant distribution especially in southern and western coastal line of Jaffna (Rajkumar et al. 2019).

Ellepola and co-workers (2018) had reported that seven true mangrove species viz., Avicennia marina, Excoecaria agallocha, Lumnitzera racemosa, Raizophora mucronata, Aegiceras corniculatum, Avicennia officinalis L. and Heritiera littoralis Dryand. are associated with Nayaru lagoon, Mullaithivu. Furthermore, they found that Avicennia maraina (relative density 60.6\%) as the most dominant species and Aegiceras corniculatum, Avicennia officinalis and Heritiera littoralis as the least abundant species. In addition, Cynometra iripa Kostel. found as a rare mangrove associate.

\section{Mangroves in Eastern Province}

Most of the mangroves in the Batticaloa district are also distributed as patches and extent of each mangrove patch is less than $0.05 \mathrm{~km}^{2}$. Large patches $\left(>1 \mathrm{~km}^{2}\right)$ of mangroves can be found in Trincomalee. Also, over the past decade, about $16 \%\left(3.01 \mathrm{~km}^{2}\right)$ of mangrove areas have disappeared (Jayasingam 2008). Shrimp aquaculture, utilization for firewood and security purposes are some of the reasons for destruction of these mangrove forests in the eastern coasts (Jayasingam 2008, Priyashantha 2018).

According to Jayasingam (2008), eastern part of the island possesses about $28-40 \%$ mangroves in the country, which includes about 20-25 true mangrove species and a similar number of mangrove associates, though the composition of mangrove vegetation was not included. A study conducted by Krishnanantham et al. (2015) found that five true mangrove species (Avicennia marina, Excoecaria agallocha, Heritiera littoralis, Lumnitzera racemose and Rhizophora apiculata) were associated with the Irakkandy lagoon. Krishnanantham et al. (2015) further indicated that Avicennia marina dominated in the area and Heritiera littoralis found to be very rare. In addition, restricted growth of Bruguiera cylindrica can be found associated with the Trincomalee lagoon (IUCN 2012).

Krishnanantham \& co-workers (2015) found that 9 mangrove associates viz., Caesalpinia bonduc (L.) Roxb., Cissus quadrangularis L., Clerodendrum inerme, Mimusops elengi L., Pandanus tectorius Parkinson ex Du Roi, Phoenix pusilla Gaertn., Premna integrifolia, Salvadora persica L. and Thespesia populnea. Being a part of the eastern province, coastline of Batticaloa possesses several common mangrove species including, Rhizophora, Brugueira, Lumnitzera, Avicennia, Sonneratia and Excoecaria, along with mangrove ferns Achrosticum and Acanthus illicifolis L., while Cerbera manghas L. can be found in association and Dolichandrone sp. can be found in Mattakkali, Batticaloa. Nevertheless, species like Xylocarpus sp. is rarely found and not properly documented in the recent past (Jayasingam 2008).

In another study, Priyashantha (2018) had reported of less disturbed mangrove forests in association with Panichchankeni lagoon, while Avicennia marina as the most frequently and densely distributed vegetation, followed by Excoecaria agallocha and Lumnitzera racemose and Hibiscus tiliaceus had been the most common mangrove associate. As evidenced by Perera \& Amarasinghe (2014), Rhizophora mucronata is the other major species in Panichchankeni lagoon, while Rhizophora apiculata and Excoecaria agallocha were the dominant species associated with Batticaloa lagoon (Perera \& Amarasinghe 2014).

While moving to the Ampara district, Prasanna et al. (2019) found eleven true mangrove species and among them, Lumnitzera racemosa and Excoecaria agallocha were recorded as the commonly distributed species. However, according to Prasanna et al. (2019), Aegiceras corniculatum, Avicennia officinalis, Bruguiera sexangula and Pemphis acidula J.R. \& G. Forst. showed restricted distribution in the Ampara district. They further found that 9 and 6 species were associated with the Panama and Pottuvil lagoons respectively and rather less number of mangrove species were associated with creeks and the estuary in the district (Table 4). 
Table 4. Distribution of Mangroves in Ampara district, Sri Lanka.

\begin{tabular}{|c|c|c|c|c|c|}
\hline Mangrove Species & $\begin{array}{r}\text { Panama } \\
\text { Lagoon } \\
\end{array}$ & $\begin{array}{c}\text { Pottuvil } \\
\text { Lagoon }\end{array}$ & $\begin{array}{r}\text { Ragamwela } \\
\text { Creek } \\
\end{array}$ & $\begin{array}{r}\text { Okanda } \\
\text { Creek } \\
\end{array}$ & $\begin{array}{r}\text { Heda oya } \\
\text { Estuary }\end{array}$ \\
\hline Aegiceras corniculatum (L.) Blanco & $\mathrm{x}$ & $\sqrt{ }$ & $\mathrm{x}$ & $\mathrm{x}$ & $\mathrm{x}$ \\
\hline Avicennia marina (Forsk.) Vierh. & $\sqrt{ }$ & $\mathrm{x}$ & $\sqrt{ }$ & $\sqrt{ }$ & $\mathrm{x}$ \\
\hline Avicennia officinalis L. & $\sqrt{ }$ & $\mathrm{X}$ & $\mathrm{X}$ & $\mathrm{X}$ & $\mathrm{x}$ \\
\hline Bruguiera gymnorrhiza (L.) Lam. & $\sqrt{ }$ & $\sqrt{ }$ & $\mathrm{x}$ & $\sqrt{ }$ & $\sqrt{ }$ \\
\hline Bruguiera sexangula (Lour.) Poir. & $\sqrt{ }$ & $\mathrm{x}$ & $\mathrm{x}$ & $\mathrm{x}$ & $\mathrm{X}$ \\
\hline Rhizophora apiculata $\mathrm{B} 1$. & $\sqrt{ }$ & $\mathrm{x}$ & $\mathrm{x}$ & $\mathrm{x}$ & $\sqrt{ }$ \\
\hline Rhizophora mucronata Lam. & $\sqrt{ }$ & $\sqrt{ }$ & $\mathrm{x}$ & $\sqrt{ }$ & $\mathrm{x}$ \\
\hline Heritiera littoralis Dryand. & $\mathrm{x}$ & $\sqrt{ }$ & $\mathrm{x}$ & $\mathrm{x}$ & $\sqrt{ }$ \\
\hline Lumnitzera racemosa Willd. & $\sqrt{ }$ & $\sqrt{ }$ & $\sqrt{ }$ & $\sqrt{ }$ & $\sqrt{ }$ \\
\hline Pemphis acidula J.R. \& G. Forst. & $\sqrt{ }$ & $\mathrm{x}$ & $\mathrm{x}$ & $\mathrm{x}$ & $\mathrm{X}$ \\
\hline Excoecaria agallocha L. & $\sqrt{ }$ & $\sqrt{ }$ & $\sqrt{ }$ & $\sqrt{ }$ & $\sqrt{ }$ \\
\hline Total number of Species & 9 & 6 & 3 & 5 & 5 \\
\hline
\end{tabular}

Note: $\sqrt{ }$ - Presence of the species, $x$ - Absence (or not recorded) of the species. [Source: Prasanna et al. (2019)]

Mangroves in the Southern Province

Southern part of Sri Lanka also has a healthy mangrove ecosystem, especially associated with Rekawa Lagoon (Hambantota District), which is surrounded by mangrove and scrub forests (about $2 \mathrm{~km}^{2}$ ) (Lowry et al. 1999). Jayatissa et al. (2002) identified 20 true mangroves and about 18 mangrove associates along the southwestern coast. Rakawa Lagoon is responsible to have the highest true mangrove diversity in southern Sri Lanka (Jayatissa et al. 2006). Mangrove forest also well enriched with 17 mangrove species including all the Sri Lankan common mangroves (Gunawardena \& Rowan 2005, Jayatissa et al. 2006). In addition, Madu Gaga estuary, which belongs to Galle District is also enriched with mangrove diversity, including a small population of Lumnitzera littorea, the species that is very rare and threatened in the island (Bambaradeniya et al. 2002). In a study, Bambaradeniya and co-workers. (2002) had recorded a total of 14 species of true mangroves and mangrove associates. Rhizophora apiculata found to be the most abundant, while Lumnitzera littorea had been the least found species.

\section{Fauna associated with mangroves}

Unique features of mangrove ecosystem, support to establish a diverse group of fauna (Miththapala 2008, Sandilyan \& Kathiresan 2012) and in Sri Lanka, it has been reported that 66 species of resident birds, 15 species of migratory birds, 37 species of lagoon fish, 9 species of mangrove crustaceans, 6 species of mammals, and 6 species of reptiles were associated with the mangrove ecosystem in the Rekawa lagoon system (Gunawardena \& Rowan 2005). In Sri Lanka, more than 100 bird species can be observed associated with mangrove forests. However, all of them are not confined to mangroves and a higher abundance of bird species could be seen associated with dry zone mangrove forests rather than the wet zone forests. Big mammals like Elephas maximus maximus and carnivore species like Panthera pardus kotiya are also regularly visit mangrove forests (Karunathilake 2003). Table 5 indicates some of the fauna associated with mangroves in the island.

Table 5. Fauna associated with mangrove swamps in Sri Lanka.

\begin{tabular}{ll}
\hline Category & Reported species \\
\hline Birds & Anastomus oscitans, Ardeola grayii, Phalacrocorax spp., Egretta spp., Halcyon \\
& pileata, Mycteria leucocephala, Streptopelia chinensis, Vanellus indicus, Owl, \\
& Plover, etc. \\
Fish & Arius maculatus, Caranx sexfasciatus, Chanos chanos, Cyprinus carpio, Epinephelus \\
& malabaricus, Etroplus maculatus, Etroplus suratensis, Lates calcarifer, Lethrinus \\
& sp., Mugil cephalus, Oreochromis mossambicus, Siganus sp., etc. \\
Crustacean & Metapenaeus dobsoni, Metapenaeus monoceros, Metopograpsus messor, \\
& Metopograpsus thukuhar, Penaeus indicus, Penaeus monodon, Penaeus \\
& semisulcatus, Perisesarma bidens, Portunus pelagicus, Portunus sanguinolentus, \\
Mollusca & Scylla serrata, Thalassina anomala, Uca annulipes, etc. \\
& Cerithidea cingulate, Nerita polita, Telescopium Telescopium, Terebralia palustris, \\
Amphibians & etc. \\
Mammals & Bufo melanostictus, Limnonectes limnocharis, etc. \\
Reptiles & Rabbits, Monkeys. \\
& Crocodylus palustris, Crocodylus porosus, Geochelone elegans, Varanus salvator, \\
\hline Sources: Karunathilake (2003); Jayasingam (2008); Prakash et al. (2017); Jonsson (2017); Priyashantha (2018).
\end{tabular}




\section{Utilization of mangroves and its products}

Mangroves utilization in the island may be a traditional practice of the nation and poverty of the local people may be a reason for them to use the mangroves (Dayalatha \& Ali 2018). Locals mainly utilized the mangrove areas to capture fish, crabs, shrimps and bivalves, and selling those for small markets and as well for household consumption (Satyanarayana et al. 2013).

Rather than that mangroves are directly utilized by the locals in many different ways (Fig. 4). Leaves of Avicennia spp. are used by the locals as agricultural manure, while stem is used as firewood and wood is used for home construction (Ranawana 2017). Branches of Avicennia spp. are used for Brush pile traditional fisheries. Prop roots from mangrove species like Rhizophora apiculata are used as fuelwood (Satyanarayana et al. 2013). Some mangrove species are cut down by the locals to obtain sticks for brooms and sweepers, making fish traps, fishing rods, stilt making, poles for fences and posts (Kaleel \& Nijamir 2017, Dayalatha \& Ali 2018).

Several mangrove species (especially Lurnnitzera and Rhizophora spp.) are used for brush pile fisheries (Ranawana 2017). Tender leaves of Avicennia marina are used as a vegetable (Katupotha 2016). Because of its very less weight, wood of Cerbera manghas is used by Sri Lankans to carve masks and puppets (Miththapala 2008). Clerodendrum inerme, Dolichandrone spathacea (L.f.) K. Schum. and Morinda citrifolia L. are specially used as firewood, while, Ceriops tagal also is used as firewood. In addition, bark of the stem is utilized in several ways such as to prepare tannin, bark decoction is used to stop hemorrhage, as an adhesive, for fishing net protection, batik and mat making. Rather than Ceriops tagal, barks of Xylocarpus spp. (X. granatum Koenig and X. molluccensis (Lam.) M.Roem.) and Bruguiera spp. (B. gymnorhiza and B. sexangula) are used to extract tannin, which is important to dye cotton fish nets and sails of boats and ships (Katupotha 2016, Ranawana 2017). Seeds of Cynometra iripa are traditionally used instead of areca nuts, while Sonneratia alba, Thespesia populnea and other Sonneratia spp. are used to feed domesticated animals like goats and cattle (IUCN 2012, Katupotha 2016). Moreover, Nypa fruticans is used to make alcohol, sugar and vinegar though in Sri Lanka it is minimally practiced at present (Ranawana 2017). Tender leaves of Sonneratia caseolaris are traditionally used as a curry and water from the boiled leaves are used as an anti-poison (Bandaranayake 1999). In addition, fruits of Sonneratia caseolaris are used to prepare a soft drink (Ranawana 2017). Rather than Sonneratia caseolaris, leaves of Acrostichum aureum and Suaeda maritima (L.) Dumort. are also used as vegetables (IUCN 2012). Pneumatophores of Sonneratia spp. are porous, and used as bottle stoppers and fishing floats (Katupotha 2016).

\section{Threats on Sri Lankan mangroves}

In Sri Lanka, mangroves are probably the most misused resource in coastal ecosystems (Ranawana 2017). Use of mangrove areas for garbage disposal indicates how poorly island people look into this valuable ecosystem (Dayalatha \& Ali 2018). During the last few decades, mangrove forests have been cleared in Sri Lanka in a rapid rate. This has led to a decline of the overall composition of mangrove forests along with a threat to disappearing some of rare species (Jayatissa et al. 2002). Estimation shows that $76 \%$ of mangrove forests in the island disappeared over the past century (Prakash et al. 2017).

Overexploitation of mangroves for traditional uses and growing population in the coastal region and hence land clearance for human settlements are some of the major and common problems for the mangrove destruction in the island. In addition, degradations of mangrove forests also have happened due to industrial activities (e.g., disposal of industrial wastes), tourism, coastal aquaculture and agriculture (e.g., vegetable fields, coastal paddy cultivation), as well due to land reclamation (Katupotha 2001, Bambaradeniya et al. 2002, Dayalatha \& Ali 2018). A study by Kaleel \& Nijamir (2017) showed that construction of tourist hotels and beach resorts in Puttalam, has led to clearance of mangroves in coastal areas of Puttalam, mainly associated with Puttalam lagoon.

Dayalatha \& Ali (2018) identified that small scale mangrove cutting for fuelwood and timber as the most common threat to the Sri Lankan mangroves and they had revealed that coastal communities who are living in the Southern coast of Sri Lanka utilize the mangroves extensively as a fuel-wood. They also had stated that mangrove species such as Excoecaria agallocha, Bruguira sexangula, Sonneratia caseolaris, Cerbera odollam Gaertn., Dolichandrone spathacea, Thespesia populnea are utilized by the communities. Dayalatha \& Ali (2018) further states that low income, quick accessibility, less usage of gas for cooking, employment status (e.g., fishing), less education and rural living are the main socio-economic factors to utilize mangroves extensively. IUCN (2012) states that Cynometra iripa and Scyphiphora hydrophyllacea have been threatened due to the extensive use of these as fuel-wood by local communities in Puttalam Lagoon. In another study, Kaleel \& Nijamir (2017) reported that clearance of mangrove forests for the expansion of large playground areas, especially in Puttalam, Kurinchipitti, Thillaiyadi and Wattala. In addition, mangroves are also subject to www.tropicalplantresearch.com 
significant grazing by cattle and goats, particularly during the dry season (IUCN 2012).

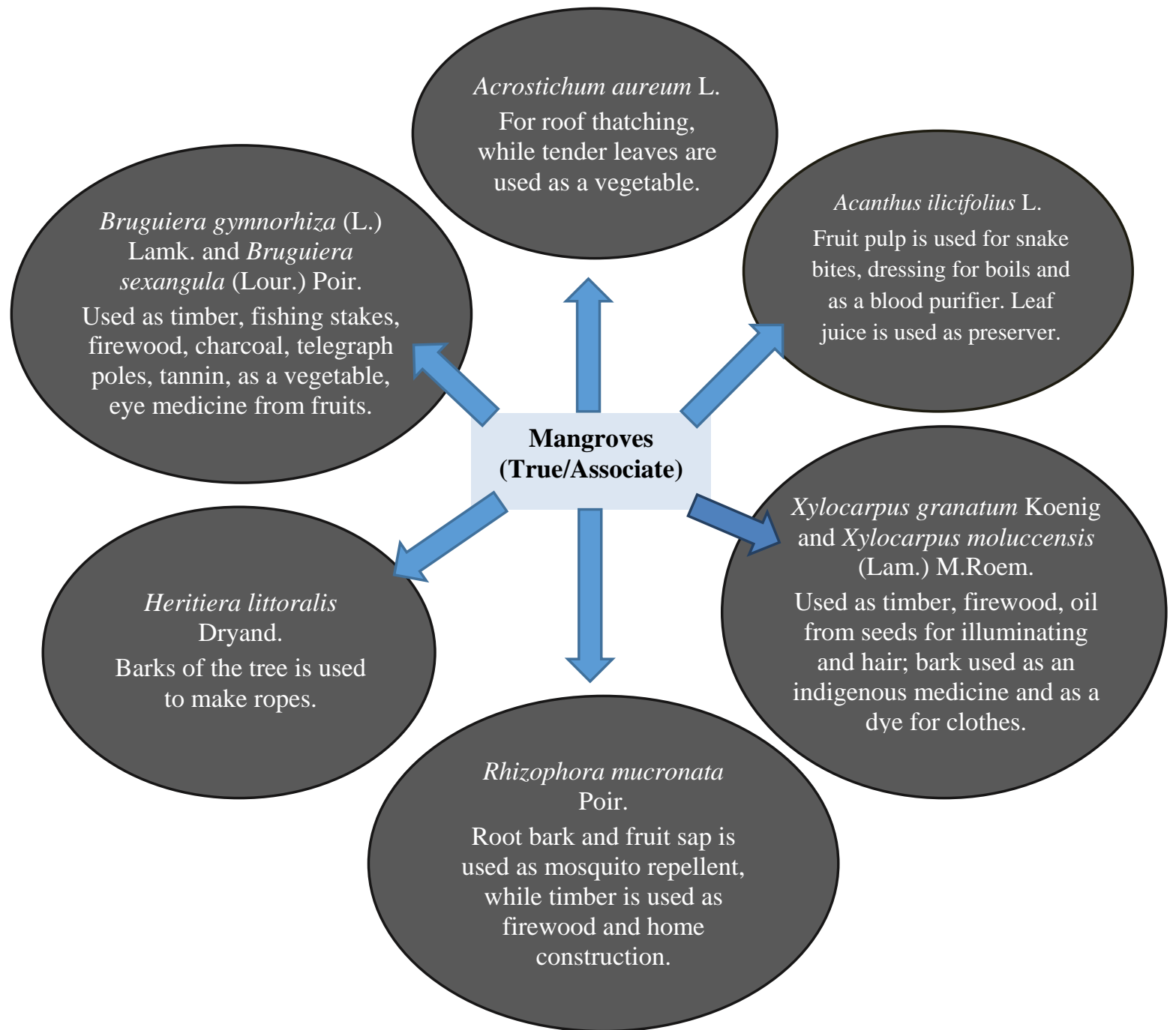

Figure 4. Some uses of Mangroves in Sri Lanka. [Source: Katupotha 2016]

Further establishment of mangrove saplings in eroded areas are also prevented due to the operation of boats at regular intervals due to its constant turbulence (Bambaradeniya et al. 2002). Mangrove patches in the island are highly vulnerable for destruction due to shrimp farming, salt manufacturing and other development projects such as road constructions (Alawathugoda et al. 2018). Shrimp farming industry caused severe damage to the mangrove ecosystem in the Puttalam district. Illegal destruction of mangrove habitat has caused number of environmental and socioeconomic effects (Munasinghe et al. 2010). Worst effect to the mangrove ecosystem in the Puttalam district had taken place during the 1992-1998, where more than 50\% of mangroves have been cleaned due to shrimp aquaculture (Harkes et al. 2015). Within 1998-2000, $13.71 \mathrm{~km}^{2}$ of mangrove forests were destroyed due to the construction of shrimp ponds. The rapid expansion of salt industry, during 2000-2015, was also responsible to deforestation of the mangrove forests in the Puttalam and it is predicted that further decline of mangrove forests by 7\% in Puttalam in 2020 (Weragodatenna \& Gunaratne 2015). However, due to the higher profits and the foreign exchange coming from shrimp aquaculture in Sri Lanka, value of the mangrove forests had been overlooked (Gunawardena \& Rowan 2005).

\section{Conservation of mangroves in Sri Lanka}

Sri Lankan government has taken many steps in order to protect this valuable ecosystem including implementing the legislations. Sri Lanka claims to be the first nation in the world to protect all its mangroves, making it illegal to cut down them anywhere in the island, and the first to open a mangrove museum (in Pabbala, Chilaw). Sri Lanka has also named as a leader for conservation of mangroves in Commonwealth countries (Mombauer 2019).

Rather than the government, many NGOs (Non-Governmental Organizations), CBOs (Community-based Organizations) and multilateral financial agencies have taken steps to conserve the mangroves in the island. Restoration of tsunami hit mangrove forests, which are located in east, west and south of the country is one of www.tropicalplantresearch.com 
the leading example of conserving mangrove vegetation (Sri Lanka National Strategy and Action Plan 2009). Nevertheless, about 23 of project sites (with 67 planting efforts) have been delivered to restore the $10-12 \mathrm{~km}^{2}$ of mangrove forest areas (Kodikara et al. 2017). However, most of the restoration practices have been failed ( 9 out of 23 project sites and 36 out of 67 planting efforts did not succeed) and about $2.0-2.2 \mathrm{~km}^{2}$ mangrove restoration were succeeded. Successful restoration practices are carried out in Kalpitiya, Pambala, and Negombo area (Kodikara et al. 2017). Frailer of mangrove restorations happened due to several reasons like planting mangrove seedlings at the inappropriate topography and hydrology, disturbance and stress caused by cattle trampling, browsing, algal accumulation and insect attacks etc. (Kodikara et al. 2017). In addition, unregulated mangrove plantations (e.g., Batticaloa and in Rekawa Lagoon) could lead to conflicts with fishermen due to loss of fishing areas (Sri Lanka National Strategy and Action Plan 2009).

Nevertheless, long-term sustainability of mangrove rehabilitation also was challenged due to lack of continuous benefits to the neighboring communities and lack of awareness (Prof. P. Vinobaba, Personal communication). Conservation of mangrove forests are also threatened by the gaps of rules and regulations. In Sri Lanka, coastal zone is governed by the Coastal Conservation Act, while mangroves are governed by the Forest Ordinance. It can create disputes due to poor enforcement of both laws (Miththapala 2008). However, still, not enough attention has been paid to conserve the very rare and endangered mangrove species and further steps have not been taken even to educate the locals about those species. In addition, any continuous observations or assessments have not been carried out on the conserved mangrove forests (Jayatissa et al. 2002).

\section{CONCLUSIONS AND RECOMMENDATIONS}

Mangroves in Sri Lanka show very little coverage, which is estimated about $0.24 \%$ of the total land. Distribution of mangroves in Sri Lanka can be found associated with all the coastal districts and hence provinces. True mangrove species such as Aegiceras corniculatum, Avicennia marina, Avicennia officinalis, Bruguiera gymnorhiza, Excoecaria agallocha, Heritiera littoralis, Lumnitzera racemose, Rhizophora mucronata and Sonneratia caseolaris are common to all the coastal provinces in the island. However, owing to several factors including hydrodynamics, species composition and community structure are varied. North Western Province bears the highest mangrove diversity followed by Western and Southern Provinces. The largest mangrove coverage is found in Jaffna district (Northern Province), while least in Matara district (Southern Province).

Being a small island nation, it can never underestimate the importance of mangrove vegetation. Since people in the island still have not seemed to properly understand the function and importance of this ecosystem, the destruction of mangroves is at a considerable rate. Multiple threats such as shrimp aquaculture, tourism, overexploitation, human settlements and a variety of other commercial and industrial activities has led to the reduction of the mangrove coverage. To overcome these issues, some measures are needed to be taken by the government. Protection of mangrove forests just by implementing laws, never to be seen as sufficient to save this valuable vegetation. Continuous monitoring of threats towards the mangrove destruction also needs to be carried out. Complete banning the entry into the mangrove forests may not be a better idea to follow.

One of the best ways to protect the mangrove vegetation would be to create coast benefits towards the adjacent locals and motivate them to protect the vegetation. This can be achieved by promoting ecotourism in the island. Other protection measures include enhancement of public awareness and avoid the overexploitation of mangroves, different stakeholder participation to protect the mangroves, continuous assessment about mangrove declining, promote research and studies on mangroves, carried out proper replanting activities by engaging the expertise or scientific communities covering all the coastal districts, continuous monitoring of restored plantation for its long-term conservation, establishment of an adequate number of mangrove nurseries and research centres and assessment about the effective land use planning.

\section{ACKNOWLEDGEMENTS}

The authors are grateful to the support rendered by Senior Prof. P. Vinobaba, Department of Zoology, Faculty of Science, Eastern University, Sri Lanka \& Mr. Ananda Kodikara, Assistant Director, Coast Conservation \& Coastal Resource Management Department, Galle Region Office, Sri Lanka.

\section{REFERENCES}

Adame MF, Kauffman JB, Medina I, Gamboa JN, Torres O, Caamal JP, Reza M \& Herrera-Silveira JA (2013) Carbon Stocks of Tropical Coastal Wetlands within the Karstic Landscape of the Mexican Caribbean. PloS One 8(2): 1-13. 
Ahmed N, Thompson S \& Glaser M (2018) Integrated Mangrove-shrimp Cultivation: Potential for Blue Carbon Sequestration. Ambio 47(4): 441-452.

Alawathugoda RMD, Premakantha KT, Pushpakumara DKNG, Sivananthawer T \& Dissanayake, MGWMWTB (2018) Mangroves in Eastern province. In: Proceeding of the International Symposium on Mangrove Ecosystems 2018 of Seacology-sudeesa Sri Lanka Mangrove Conservation Program. 27 July 2018, pp. 1.

Alongi DM (2002) Present State and Future of the World's Mangrove Forests. Environmental Conservation 29(3): 331-349.

Amarasinghe MD (1997) Leaf litter Decomposition in the Mangrove Ecosystems of Dutch bay. Sri Lanka Journal of Aquatic Sciences 2: 21-28.

Andrade KVSde, Holanda FSR, Santos Tde O, Santana MBS \& Araújo Filho RND (2018) Mangrove Soil in Physiographic Zones in the Sao Francisco River Estuary. Florestae Ambiente 25(2): 1-9.

Arulpragasam KD (2000) Introduction. In: Cooray PG, Abeywickrama BA, Amarasinghe M, Arulpragasam KD, Dias P, Watson M \& Wijesinghe LCAdeS (eds) Natural Resources of Sri Lanka 2000. The National Science Foundation, Colombo, Sri Lanka, pp. 1-7.

Asbridge E, Lucas R, Rogers K \& Accad A (2018) The Extent of Mangrove Change and Potential for Recovery Following Severe Tropical Cyclone Yasi, Hinchinbrook Island, Queensland, Australia. Ecology and Evolution 8(21): 10416-10434.

Asbridge E, Lucas R, Ticehurst C \& Bunting P (2016) Mangrove Response to Environmental Change in Australia's Gulf of Carpentaria. Ecology and Evolution 6(11): 3523-3539.

Ashton EC (2008) The Impact of Shrimp Farming on Mangrove Ecosystems. In: CAB Reviews: Perspectives in Agriculture, Veterinary Science, Nutrition and Natural Resources. pp. 1-12.

Bambaradeniya CNB, Ekanayake SP, Kekulandala LDCB, Fernando RHSS, Samarawickrama VAP \& Priyadharshana TGM (2002) An Assessment of the Status of Biodiversity in the Maduganga Mangrove Estuary. Occ. Pap. IUCN, Sri Lanka., 1, pp. 49.

Bandaranayake WM (1999) Economic, Traditional and Medicinal Uses of Mangroves. In: Issue 28 of AIMS Report. Australian Institute of Marine Science, $82 \mathrm{p}$.

Blankespoor B, Dasgupta S \& Lange GM (2017) Mangroves as a Protection from Storm Surges in a Changing Climate. Ambio 46(4): 478-491.

Boone JK \& Bhomia RK (2017) Ecosystem Carbon Stocks of Mangroves across Broad Environmental Gradients in West-central Africa: Global and Regional Comparisons. Plos One 12(11): 1-17.

Das L, Patel R, Salvi H \& Kamboj RD (2019) Assessment of Natural Regeneration of Mangrove with Reference to Edaphic Factors and Water in Southern Gulf of Kachchh, Gujarat, India. Heliyon 5(8): 1-8.

Das S \& Vincent JR (2009) Mangroves Protected Villages and Reduced Death Toll during Indian Super Cyclone. Proceedings of the National Academy of Sciences of the United States of America 106(18): 73577360.

Dayalatha WKV \& Ali SKM (2018) The Use of Mangroves as a Source of Fire Wood: A Socio-economic Study on Selected Mangroves in Southern Sri Lanka. Journal of Social Sciences and Humanities Review 3(3): 175-192.

De Silva M \& De Silva PK (1998) Status, Diversity and Conservation of Mangrove Forests of Sri Lanka. Journal of South Asian Natural History 3: 79-102.

Ellepola G, Ranawana KB \& Chandrajith R (2018) Assessment of Mangrove Vegetation Distribution, Fishery and Water Quality in the Nayaru Lagoon, Mulativu, Sri Lanka. In: Proceeding of the International Symposium on Mangrove Ecosystems 2018 of Seacology-sudeesa Sri Lanka Mangrove Conservation Program. 27 July 2018, pp. 2.

FAO (2007) The world's Mangroves 1980-2005. FAO, Rome, Italy, pp. 7-15.

Gandhi S \& Jones TG (2019) Identifying Mangrove Deforestation Hotspots in South Asia, Southeast Asia and Asia-Pacific. Remote Sensing 11(6): 1-27.

Gao Y, Zhou J, Wang L, Guo J, Feng J, Wu H \& Lin G (2019) Distribution Patterns and Controlling Factors for the Soil Organic Carbon in Four Mangrove Forests of China. Global Ecology and Conservation 17: 1-14.

Geekiyanage N, Vithanage M, Wijesekara H \& Pushpakumara G (2015) State of the Environment, Environmental Challenges and Governance in Sri Lanka. In: Environmental Challenges and Governance: Diverse Perspectives from Asia. Routledge, Taylor and Francis Group., Abingdon, United Kingdom, pp. 92 108.

Guannel G, Arkema K, Ruggiero P \& Verutes G (2016) The Power of Three: Coral Reefs, Seagrasses and 
Mangroves Protect Coastal Regions and Increase their Resilience. PloS One 11(7): 1-22.

Gunathilaka MDKL \& Chandrasekara CMKNK (2017) Assessing the Degradation of Mangrove Ecosystems in the Puttalam Lagoon. In: Proceedings of the Annual Research Symposium, Faculty of Arts, University of Colombo. November 2017, pp, 25.

Gunatilleke N, Pethiyagoda R \& Gunatilleke S (2008) Biodiversity of Sri Lanka. Journal of the National Science Foundation of Sri Lanka 36(Special Issue): 25-61.

Gunawardena AR, Nissanka SP, Dayawansa, NDK \& Fernando TT (2016) Above Ground Biomass Estimation of Mangroves Located in Negombo-Muthurajawela Wetland in Sri Lanka using ALOS PALSAR Images. Tropical Agricultural Research 27(2): 137-146.

Gunawardena M \& Rowan JS (2005) Economic Valuation of a Mangrove Ecosystem Threatened by Shrimp Aquaculture in Sri Lanka. Environmental Management 36(4): 535-550.

Hamilton SE \& Casey D (2016) Creation of a High Spatio-temporal Resolution Global Database of Continuous Mangrove Forest Cover for the $21^{\text {st }}$ Century (CGMFC-21). Global Ecology and Biogeography 25(6): 729738.

Harkes IHT, Drengstig A, Kumara MP, Jayasinghe JMPK \& Huxham M (2015) Shrimp Aquaculture as a Vehicle for Climate Compatible Development in Sri Lanka. The Case of Puttalam Lagoon. Marine Policy 61: 273-283.

Hrudayanath T, Dibyajyoti S \& Swagat KD (2016) The Genus Avicennia, a Pioneer Group of Dominant Mangrove Plant Species with Potential Medicinal Values: A Review. Frontiers in Life Science 9(4): 267291.

IUCN (2012). An Environmental and Fisheries Profile of the Puttalam Lagoon System. Regional Fisheries Livelihoods Programme for South and Southeast Asia (GCP/RAS/237/SPA) Field Project Document 2011/LKA/CM/06, pp. 55-59.

Jayasingam T (2008) Eastern Province Biodiversity Profile and Conservation Action Plane. Biodiversity Secretariat, Ministry of Environment and Natural Resources., Colombo, Sri Lanka, pp. 19-22.

Jayatissa LP (2012) Present Status of Mangroves in Sri Lanka. In: Weerakoon DK \& Wijesundara S (eds) The National Red List 2012 of Sri Lanka; Conservation Status of the Fauna and Flora. Ministry of Environment., Colombo, Sri Lanka, pp. 197-199.

Jayatissa LP, Dahdouh-Guebas F \& Koedam N (2002) A Review of the Floral Composition and Distribution of Mangroves in Sri Lanka. Botanical Journal of the Linnean Society 138(1): 29-43.

Jayatissa LP, Weerakkody WAT, Dissanayake NP, Senanayake G \& Sanjeewani S (2006) A Study of Salt Secretion by Mangroves of Rekawa Lagoon, Sri Lanka. Ruhuna Journal of Science 1: 1-15.

Jonsson M (2017) Social-ecological Resilience of Mangroves and Coastal Households in Batticaloa District, Sri Lanka, (Master's thesis). Norwegian University of Life Sciences, Norway. Available from: https:// www.easybib.com/guides/citation-guides/apa-format/how-to-cite-a-thesis dissertation-apa/ (accessed: 16 Apr. 2020).

Kaleel MIM \& Nijamir K (2017) The Environmental Challenges of Declining Mangroves: An Analytical Survey in Puttalam District in Sri Lanka. World News of Natural Sciences 14: 106-115.

Karunathilake KMBC (2003) Status of Mangroves in Sri Lanka. Journal of Coastal Development 7(1): 5-9.

Kathiresan K \& Bingham BL (2001) Biology of Mangroves and Mangrove Ecosystems. Advances in Marine Biology 40: 81-251.

Katupotha KNJ (2001) Degradation of Mangrove Swamps in Sri Lanka. In: Proceedings of the Seventh Annual Forestry and Environment Symposium 2001 of the Department of Forestry and Environmental Science. University of Sri Jayewardenepura, Sri Lanka, 19 p.

Katupotha KNJ (2016) Mangroves in Lagoon Ecosystems: A Neglected Habitat in Sri Lanka. Wildlanka 4(3): 79-105.

Kodikara KAS, Mukherjee N, Jayatissa LP, Dahdouh-Guebas F \& Koedam N (2017) Have Mangrove Restoration Projects Worked? An In-depth Study in Sri Lanka. Restoration Ecology 25(5): 705-716.

Krishnanantham K, Seneviratne YBMCJ \& Jayamanne SC (2015) A Preliminary Study on Vegetation Structure and Mangrove Diversity in Irakkandy lagoon, Trincomalee. Journal of Tropical Forestry and Environment 5: 59-70.

Lowry K, Pallewatte N \& Dainis AP (1999) Policy-relevant Assessment of Community-level Coastal Management Projects in Sri Lanka. Ocean and Coastal Management 42(8): 717-745.

Mathanraj S \& Kaleel MIM (2015) Threats of Mangrove Flora and the Management Actions; a Case Study in 
Kaluwanchikudy Area. In: $5^{\text {th }}$ International Symposium 2015. South Eastern University, pp. 443-449.

Menéndez P, Losada IJ, Torres-Ortega S, Toimil A \& Beck MW (2019) Assessing the Effects of Using Highquality Data and High-resolution Models in Valuing Flood Protection Services of Mangroves. PloS One 14(8): 1-14.

Miththapala S (2008) Mangroves. Coastal Ecosystems Series Volume 2. Ecosystems and Livelihoods Group Asia, IUCN, Colombo, Sri Lanka, pp. 1-28.

Moity N, Delgado B \& Salinas-de-León P (2019) Mangroves in the Galapagos Islands: Distribution and Dynamics. PloS One 14(1): 1-35.

Mombauer D (2019) Community-based Mangrove Conservation and Restoration Using Local and Technical Knowledge. SLYCAN Trust, pp. 1-16.

Mukherjee N, Sutherland WJ, Khan MN, Berger U, Schmitz N, Dahdouh-Guebas F \& Koedam N (2014) Using Expert Knowledge and Modeling to Define Mangrove Composition, Functioning, and Threats and Estimate Time Frame for Recovery. Ecology and Evolution 4(11): 2247-2262.

Munasinghe MN, Stephen C, Abeynayake P \& Abeygunawardena IS (2010) Shrimp Farming Practices in the Puttallam District of Sri Lanka: Implications for Disease Control, Industry Sustainability, and Rural Development. Veterinary Medicine International 2010: 1-7.

Nabeelah Bibi S, Fawzi M M, Gokhan Z, Rajesh J, Nadeem N, Rengasamy KRR, Albuquerque RDDG \& Pandian SK (2019) Ethnopharmacology, Phytochemistry, and Global Distribution of Mangroves-A Comprehensive Review. Marine Drugs 17(4): 1-82.

Nayanananda OK (2007) The Study of Economic Significance of Coastal Region of Sri Lanka in the Context of Environmental Changes of Pre and Post Tsunami. Coast Conservation Department and the Ministry of Environment and Natural Resources. Available from: http://www.coastal.gov.lk/images/pdf/Paper_1.pdf. (accessed: 26 Mar. 2020).

Nehemia A \& Kochzius M (2017) Reduced Genetic Diversity and Alteration of Gene Flow in a Fiddler Crab Due Toto Mangrove Degradation. Plos One 12(8): 1-20.

Packiyanathan R \& Wijesundara CS (2016) Distribution of Mangrove Species in the Islands of Jaffna Peninsula, Sri Lanka. In: Proceedings of the International Forestry and Environment Symposium 2016, Department of Forestry and Environmental Science. University of Sri Jayewardenepura, Sri Lanka, pp. 14.

Paul BG \& Vogl CR (2011) Impacts of Shrimp Farming in Bangladesh: Challenges and Alternatives. Ocean and Coastal Management 54(3): 201-211.

Perera KARS \& Amarasinghe M.D (2014) Effect of Vegetation Structure on Carbon Assimilation Capacity of Mangrove Ecosystems in the East Coast of Sri Lanka. Journal of Coastal Development 17: 1410-5217.

Perera KARS, Amarasinghe MD and Somaratna S (2013) Vegetation Structure and Species Distribution of Mangroves along a Soil Salinity Gradient in a Micro Tidal Estuary on the North-western Coast of Sri Lanka. American Journal of Marine Science 1(1): 7-15.

Pham TD, Xia J, Ha NT, Bui DT, Le NN \& Tekeuchi W (2019) A Review of Remote Sensing Approaches for Monitoring Blue Carbon Ecosystems: Mangroves, Seagrasses and Salt Marshes During 2010-2018. Sensors (Basel, Switzerland) 19(8): 1-37.

Prakash TGSL, Weerasingha A, Withanage PWABM \& Kusuminda TGT (2017) Mangrove Diversity in Muthurajawela and Negombo Lagoon Wetland Complex, Sri Lanka: Insights for Conservation and Management. Wildlanka 5(3): 99-106.

Prasanna MGM, Ranawana KB \& Jayasuriya KMGG (2019) Species Composition, Abundance and Diversity of Mangroves in Selected Sites in Amprara District in the East Coast of Sri Lanka. Ceylon Journal of Science 48(2): 169-175.

Priyashantha AKH (2018) Preliminary Investigation of Socio-ecological Impacts of the Proposed Industrial Aquaculture Park (PIAP) at Vaharai, (B.Sc. Thesis). Eastern University, Vantharumoolai, Sri Lanka.

Quadros AF \& Zimmer M (2017) Dataset of "True Mangroves" Plant Species Traits. Biodiversity Data Journal 5: 1-21.

Rajkumar P, Wijesundara C \& Ranawana K (2019) Distribution of Mangrove Species in the Jaffna District, Sri Lanka. In: Proceedings of the $24^{\text {th }}$ International Forestry and Environment Symposium 2019 of the Department of Forestry and Environmental Science. University of Sri Jayewardenepura, Sri Lanka, pp. 37.

Ranawana KB (2017) Mangroves of Sri Lanka.Seacology-Sudeesa Mangrove Museum 1(1): 25-28.

Reef R \& Lovelock C E (2015) Regulation of Water Balance in Mangroves. Annals of Botany 115(3): 385-395. Saddhe AA, Jamdade RA \& Kumar K (2016) Assessment of Mangroves from Goa, West Coast India Using 
DNA Barcode. Springer Plus 5(1): 1-10.

Samarakoon J \& Samarawickrama S (2012) An Appraisal of Mangrove Management in Micro-tidal Estuaries and Lagoons in Sri Lanka. IUCN Sri Lanka Country Office, Colombo, Sri Lanka, pp. 1-115.

Sandilyan S \& Kathiresan K (2012) Mangrove Conservation: A Global Perspective. Biodiversity and Conservation 21: 3523-3542.

Sarathchandra C, Kambach S, Ariyarathna SC, Xu J, Harrison RD \& Wickramasinghe S (2018) Significance of Mangrove Biodiversity Conservation in Fishery Production and Living Conditions of Coastal Communities in Sri Lanka. Diversity 10(2): 1-12.

Satyanarayana B, Bhanderi P, Debry M, Maniatis D, Foré F, Badgie D, Jammeh K, Vanwing T, Farcy C, Koedam N \& Dahdouh-Guebas F (2012) A Socio-ecological Assessment Aiming at Improved Forest Resource Management and Sustainable Ecotourism Development in the Mangroves of Tanbi Wetland National Park, The Gambia, West Africa. Ambio 41(5): 513-526.

Satyanarayana B, Mulder S, Jayatissa LP \& Dahdouh-Guebas F (2013) Are the Mangroves in the GalleUnawatuna Area (Sri Lanka) at Risk? A Social-ecological Approach Involving Local Stakeholders for a Better Conservation Policy. Ocean and Coastal Management 71: 225-237.

Sri Lanka National Strategy and Action Plan (2009) Mangroves for the Future Programme. IUCN Sri Lanka Country Office, Colombo, Sri Lanka, pp. 81-86.

Van der Stocken T, Carroll D, Menemenlis D, Simard M \& Koedam N (2019) Global-scale Dispersal and Connectivity in Mangroves. Proceedings of the National Academy of Sciences of the United States of America 116(3): 915-922.

Walcker R, Laplanche C, Herteman M, Lambs L \& Fromard F (2019) Damages Caused by Hurricane Irma in the Human-degraded Mangroves of Saint Martin (Caribbean). Scientific Reports 9(1): 1-11.

Walters BB, Rönnbäck P, Kovacs J M, Crona B, Hussain SA, Badola R, Primavera JH, Barbier E \& DahdouhGuebas F (2008) Ethnobiology, Socio-economics and Management of Mangrove Forests: A Review. Aquatic Botany 89(2): 220-236.

Wang L, Mu M, Li X, Lin P \& Wang W. (2011a). Differentiation between True Mangroves and Mangrove Associates Based on Leaf Traits and Salt Contents. Journal of Plant Ecology 4(4): 292-301.

Wang W, Yan Z, You S, Zhang Y, Chen L \& Lin G (2011b). Mangroves: Obligate or Facultative Halophytes? A Review. Trees 25(6): 953-963.

Weiss C, Weiss J, Boy J, Iskandar I, Mikutta R \& Guggenberger G (2016) Soil Organic Carbon Stocks in Estuarine and Marine Mangrove Ecosystems are Driven by Nutrient Colimitation of P and N. Ecology and Evolution 6(14): 5043-5056.

Wen M, Lin X, Xie M, Wang Y, Shen X, Liufu Z, Wu CI, Shi S \& Tang T (2016) Small RNA Transcriptomes of Mangroves Evolve Adaptively in Extreme Environments. Scientific Reports 6: 1-12.

Weragodatenna DDD \& Gunaratne ABAK (2015) Change Detection of Mangrove Coverage in Puttalam Lagoon of Sri Lanka Using Satellite Remote Sensing Techniques. Journal of the National Aquatic Resources Research and Development Agency 44: 45-57.

Wu ZQ, Zou Q, Chang T, Zhang D \& Huang LL (2018) Seasonal Dynamics of the Juvenile Fish Community Structure in the Maowei Sea Mangroves. Plos One 13(2): 1-15.

Yaney-Keller A, Santidrián Tomillo P, Marshall JM \& Paladino FV (2019) Using Unmanned Aerial Systems (UAS) To Assay Mangrove Estuaries on the Pacific Coast of Costa Rica. PloS One 14(6): 1-20.

Zvonareva S, Kantor Y, Li X \& Britayev T (2015) Long-term Monitoring of Gastropoda (Mollusca) Fauna in Planted Mangroves in Central Vietnam. Zoological Studies 54: 1-16. 